\title{
INTERVENSI BAGI ANAK YANG TERISOLIR MELALUI PERMAINAN “ELANG DAN ANAK AYAM"
}

\author{
Karsih \\ e-mail: karsih5979@gmail.com \\ Bimbingan dan Konseling FIP Universitas Negeri Jakarta
}

\begin{abstract}
Abstrak: Penelitian ini dilakukan untuk melihat pengaruh program intervensi dengan teknik bermain peran "Elang dan Anak Ayam" untuk meningkatkan kemampuan interaksi sosial pada siswa terisolir. Penelitian dilakukan di SDN Utan Kayu Selatan 13 Pagi pada bulan Oktober sampai dengan Desember 2013 Jakarta Timur dengan pendekatan single subject reseacrh. Subjek penelitian adalah satu orang siswa yang mengalami kesulitan dalam interaksi sosial (terisolir). Untuk memperoleh gambaran yang mendalam tentang subjek analisis, data penelitian dikumpulkan melalui wawancara dan observasi. Kemudian data dianalisis dengan menggunakan diagram analisis. Analisis kondisi digunakan untuk melihat perubahan kondisi, yaitu kondisi Baseline dan Intervention. Sementara, interkondisi adalah analisis yang digunakan untuk melihat perubahan antara kondisi yang satu dengan kondisi lainnya. Hasil penelitian menunjukkan dari kondisi Baseline ke Intervention menunjukkan terjadi peningkatan kemampuan interaksi sosial. Peningkatan kemampuan siswa dalam melakukan interaksi sosial meliputi indikator, interaksi positif dengan teman sebaya, berpartisipasi dalam aktivitas kelompok, dan responsif terhadap orang lain.
\end{abstract}

Kata-kata Kunci: metode intervensi, teknik bermain peran, interaksi sosial.

\section{INTERVENTION TO ISOLATED CHILDREN THROUGH "EAGLE AND CHICKS" GAME}

\begin{abstract}
This study was conducted to discover whether intervention program with role playing technique (Eagle and chicks) was able to increase the capability of social interaction of a isolation student in SDN Utan Kayu Selatan 13 Pagi, East Jakarta. This study was conducted from October through December 2013 using a single subject approach. The participant in this study included one child with social interaction difficulties. The data were collected through interview and observation. The analysis of data from a single subject experimental research used a chart analysis including the analysis results and analysis of conditions. Analysis of the conditions was used to analyze the changes in the conditions, the conditions of Baseline and Intervention. While inter-condition analysis is the analysis was used to analyze the change from one condition to another condition. The results showed a decreased ability of Baseline conditions and an increasing ability in Intervention condition. The increased capabilities included indicators of positive interaction with peer, participating in group activities, and responsive to others.
\end{abstract}

Keywords: intervention method, role playing technique, social interaction.

\section{PENDAHULUAN}

Kehidupan manusia tumbuh dan berkembang dalam suatu rentang yang berawal dari masa konsepsi, kelahiran, kanak-kanak, remaja, dewasa, hingga usia lanjut. Pada setiap tahap, masing-masing individu mempunyai suatu pengalaman unik yang akan menjadi dasar bagi pembentukan karakteristik pribadi dan mempengaruhi pola perilaku serta persepsi dalam melihat berbagai fenomena di lingkungannya.

Anak usia dini, yaitu anak-anak yang berada pada rentang usia 0-8 tahun, oleh National for the Education of Young Children (NAEYC) dibedakan menjadi tiga kelompok berdasarkan tingkat usia perkembangannya, yaitu 0-3 tahun, 3-5 tahun, dan 6-8 tahun. Sejalan dengan hal itu, perkembangan anak dikategorikan berdasarkan ruang lingkup sosialisasinya. Pada usia 1 tahun, anak-anak hanya bermain dengan anggota keluarganya. Umur 2 tahun, anak mulai berminat bermain bersama. Pada usia ini, anak belum membedakan apakah mereka bermain dengan perempuan atau laki-laki. Umur 2,5 tahun, anak mulai dapat bermain secara berteman, tetapi belum dapat bekerjasama dalam kelompoknya. Umur 3 tahun, anak dapat bermain dalam kelompok. Pada usia 3,5 tahun, anak mulai mampu bersaing atas nama 
kelompok dengan kelompok lain. Pada usia 4 tahun, anak sudah dapat bermain dengan teman. Mereka senang mempunyai hubungan dengan siapa saja, atau mampu bermain dengan teman laki-laki maupun perempuan. Pada usia 6 tahun, makin banyak kegiatan yang dilakukan anak dalam kelompok. Kegiatan bermainnya kebanyakan merupakan permainan dengan aturan, bahkan kegiatan bermain sudah melibatkan dua orang saja, selain kelompok. Mereka juga sudah dapat diajak bertanding (Patmonodewo, 2002:53-54).

Bermain merupakan bagian dari aktivitas yang dilakukan anak. Sejak lahir seorang anak sudah mulai bermain (Piaget dalam Naisaban, 1977). Permainan ini jelas terlihat dalam gerakan-gerakan kaki, tangan, dan bagian tubuh lain untuk mengeksplorasi lingkungan serta berinteraksi dengan orang-orang di sekitarnya.

Sebagai makhluk sosial, anak seperti juga individu pada umumnya, diharapkan mampu berinteraksi dengan lingkungan sekitarnya. Oleh karena itu, anak perlu menguasai keterampilanketerampilan sosial. Keterampilan sosial pada anak didefinisikan sebagai kemampuan untuk beradaptasi dengan lingkungan yang ditunjukkan dengan kemampuan untuk mempersepsi orang lain secara tepat, asertif, responsif, berempati, memiliki rasa humor, ramah kepada teman sebaya, dan santun kepada orang dewasa. Keterampilan tersebut harus mulai dikembangkan sedini mungkin, misalnya dengan memberi waktu yang cukup kepada anak untuk bermain, dan bernteraksi dengan teman sebaya.

Hubungan antarteman sebaya (peer relationship) merupakan salah satu aspek penting dari perwujudan keterampilan sosial dan memiliki kontribusi yang sangat besar terhadap perkembangan sosial maupun kognitif anak. Selain itu, hubungan antarteman sebaya juga berkontribusi terhadap keefektifan fungsi individu sebagai orang dewasa. Prediktor terbaik bagi kemampuan adaptasi seorang anak ketika ia dewasa bukan prestasi akademiknya, melainkan kualitas hubungan sosialnya dengan anak-anak lain (Hartup dalam Vasta, Haith, \& Miller, 1999:643). Anak yang tidak disukai oleh banyak anak lain, sebagian besar kasusnya pada masa usia dini karena sikap dan perilaku agresif. Anak-anak ini biasanya senang mengganggu teman (mengambil atau merebut mainan), berkata kasar, menyakiti secara fisik (memukul, menjambak), dan membuat keributan di kelas. Hal ini menyebabkan ruang gerak interaksi anak menjadi sempit karena dijauhi atau terisolir dalam kelompoknya.

Mengingat betapa pentingnya kualitas per- temanan bagi anak, di mana dalam interaksi tersebut berbagai aspek perkembangan anak akan berfungsi secara efektif, maka anak-anak dengan kondisi tersebut perlu dibantu. Guru di sekolah dasar memiliki tugas dan kewajiban yang salah satunya menyelenggarakan layanan bimbingan dan konseling kepada siswa secara terintegrasi dalam kegiatan pembelajaran.

Secara umum, latar belakang perlunya layanan bimbingan dan konseling berhubungan erat dengan pencapaian tujuan pendidikan nasional, yaitu meningkatkan kualitas sumber daya manusia Indonesia yang beriman dan bertakwa terhadap Tuhan Yang Maha Esa, berbudi pekerti luhur, berkepribadian, berdisiplin, bekerja keras, tangguh, bertanggung jawab, mandiri, cerdas dan terampil serta sehat jasmani dan rohani. Untuk mewujudkan tujuan tersebut, perlu mengintegrasikan seluruh komponen yang ada dalam pendidikan, salah satunya komponen bimbingan dan konseling. Selain itu, Pendidikan Nasional berfungsi mengembangkan kemampuan dan membentuk watak serta peradaban bangsa yang bermartabat dalam rangka mencerdaskan kehidupan bangsa dan bertujuan untuk berkembangnya potensi peserta didik agar menjadi manusia yang beriman dan bertakwa kepada Tuhan Yang Maha Esa, berakhlak mulia, sehat, berilmu, cakap, kreatif, mandiri, dan menjadi warga negara yang demokratis serta bertanggung jawab (Undang-undang Sistem Pendidikan Nasional No. 20 tahun 2003 pasal 3). Lebih lanjut, pendidikan dasar bertujuan memberi bekal kemampuan dasar kepada siswa untuk mengembangkan kehidupannya sebagai pribadi, anggota masyarakat, warga Negara, dan anggota umat manusia, serta mempersiapkan siswa untuk mengikuti pendidikan menengah (Peraturan Pemerintah No. 28 tahun 1990 pasal 3).

Dengan demikian, pada dasarnya pendidikan tidak hanya berfungsi mengembangkan kemampuan kognitif siswa, tetapi seluruh aspek yang ada pada dirinya, termasuk pengembangan karakter, sehingga dapat dicapai perkembangan yang optimal dari setiap siswa. Upaya ini merupakan integrasi ketiga komponen pendidikan sebagaimana yang telah dipetakan dalam kurikulum 1975, yaitu manajemen dan supervisi, pembelajaran bidang studi, dan bimbingan dan konseling. Pelayanan BK diletakkan sebagai bagian dari kurikulum yang isinya dipilah dalam tiga hal, yaitu kelompok mata pelajaran, muatan lokal, dan materi pengembangan diri (Permendiknas No. 22 tahun 2006 tentang Standar Isi).

Anak pada usia SD sebagaimana yang telah dideskripsikan sebelumnya, memiliki lingkungan sosial yang mulai meluas. Mereka seringkali mengalami 
hambatan dalam perkembangan sosial emosionalnya. Pada masa ini, keterampilan sosial menjadi sangat penting dalam mendukung keberhasilan sosialisasi anak di sekolah maupun lingkungan yang lebih luas. Sebuah penelitian menunjukkan bahwa kematangan sosial emosional anak pada masa TKakan berpengaruh pada masa-masa transisi, baik di Sekolah Dasar (SD), maupun tingkat pendidikan selanjutnya, bahkan ketika bekerja (The Child Mental Health Foundations and Agencies Network, 2000:7).

Anak-anak yang mengalami hambatan dalam aspek ini, umumnya menjadi anak yang terisolir. Padahal, hambatan dalam aspek sosial emosional dapat berdampak pada berbagai aspek lainnya. Oleh karena itu, perlu peran guru kelas untuk memberikan layanan bimbingan dan konseling kepada anak. Bimbingan dan konseling (BK) merupakan bantuan kepada individu dalam menghadapi persoalan-persoalan yang dapat timbul dalam hidupnya. Persoalan yang mungkin saja dialami dapat terkait dengan masalah pribadi, sosial, ataupun belajar. Pemberian bantuan semacam ini di sekolah sangat tepat agar setiap siswa berkembang seoptimal mungkin. Dengan demikian, BK menjadi bidang layanan khusus dalam keseluruhan kegiatan pendidikan di sekolah yang ditangani oleh tenaga-tenaga ahli dalam bidang tersebut. Hanya saja, kegiatan tersebut tidak diberikan oleh Guru BK di sekolah dasar secara khusus seperti di jenjang pendidikan SMP dan SMA. Guru kelas harus menjalankan tugasnya secara menyeluruh, baik tugas menyampaikan semua materi pelajaran (kecuali mata pelajaran Agama dan Penjaskes) dan memberikan layanan bimbingan konseling kepada semua siswa tanpa terkecuali. Oleh karena itu, layanan ini dapat diberikan secara terintegrasi dalam perannya menjadi guru kelas.

Salah satu upaya yang dapat dilakukan dalam rangka memberikan layanan bantuan kepada siswa di sekolah dasar untuk menghadapi persoalanpersoalan yang dapat timbul dalam hidupnya adalah melalui kegiatan bermain yang terintegrasi. Kegiatan bermain merupakan salah satu bentuk interaksi utama antarteman sebaya di kalangan anak-anak. Bermain yang memiliki sifat spontan dan bebas, dapat menjadi media terapi bagi anak. Tanpa disadari, anak akan belajar bagaimana melindungi teman-temannya, saling menjaga, dan tidak menyakiti.

Pentingnya bermain bagi anak juga berkaitan dengan fungsi otak (Semiawan, 2002:25). Sebagaimana yang diketahui, kedua belahan otak, kiri dan kanan, memiliki fungsi yang berbeda. Belahan otak kiri memiliki fungsi, ciri, dan respon untuk berpikir logis, teratur, dan linier. Sedangkan fungsi otak kanan, terutama dikembangkan untuk mampu berpikir holistik, imajinatif, dan kreatif. Bila anak belajar formal (seperti banyak menghafal) pada usia muda, maka belahan otak kiri yang berfungsi linier, logis, dan teratur, amat dipentingkan perkembangannya, dan ini sering mengakibatkan fungsi belahan otak kanan yang banyak digunakan dalam berbagai permainan terabaikan. Akibatnya, anak kelak akan tumbuh dengan sikap yang cenderung bermusuhan terhadap sesama teman atau orang lain (Clark, 1986). Hal tersebut menunjuk pada suatu pertumbuhan mental yang kurang sehat.

Hal yang sangat penting di sini adalah, disadari atau tidak, anak-anak belajar banyak hal dari bermain, sehingga bermain memiliki pengaruh dalam tumbuh kembang seorang anak. Dalam konteks ini, bermain tidak hanya mengandung esensi membuat anak menjadi gembira, tetapi merupakan sarana atau cara anak untuk belajar tentang tubuhnya, lingkungan, ideide, kejadian, orang atau objek-objek di sekelilingnya.

Sebagaimana yang juga telah dideskripsikan di awal, kegiatan pembelajaran yang dilakukan guru hendaknya dapat mengembangkan seluruh aspek pada diri anak. Kegiatan pembelajaran juga dapat direncanakan sebagai bentuk intervensi yang dapat mengembangkan perilaku positif anak, atau secara bertahap mengatasi berbagai hambatan perkembangan yang dialami anak. Oleh karena itu, guru perlu memilih metode pembelajaran yang tepat, yang dapat direncanakan untuk tujuan tersebut. Salah satunya adalah mengintegrasikan aktivitas bermain dalam kegiatan pembelajaran. Kegiatan ini juga merupakan rancangan intervensi sebagai bentuk layanan konseling bagi anak-anak yang mengalami hambatan dalam perkembangan sosial emosionalnya, antara lain anak-anak yang terisolir.

Salah satu metode bermain yang paling dekat dengan karakteristik anak adalah kegiatan bermain peran. Dalam kegiatan ini, anak menggunakan banyak simbol untuk merepresentasikan pengalaman nyata sehari-hari, seperti bermain dokter-dokteran, menjadi guru, atau berperan menjadi ibu. Melalui bermain peran (role playing), anak mencoba mengeksplorasi hubungan interpersonal dengan cara memperagakan dan mendiskusikannya sehingga secara bersama-sama mereka dapat mengeksplorasi perasaan, sikap, nilai, dan berbagai strategi pemecahan masalah.

Sebagai suatu metode pembelajaran, bermain peran berakar pada dimensi pribadi dan sosial. Dari dimensi pribadi, metode ini berusaha membantu anak menemukan makna dari lingkungan sosial 
yang bermanfaat bagi dirinya. Juga melalui metode ini, anak diajak untuk belajar memecahkan masalah pribadi yang sedang dihadapinya dengan bantuan kelompok sosial yang beranggotakan teman-teman sekelas. Sedangkan dari dimensi sosial, metode ini memberikan kesempatan kepada anak untuk bekerja sama dalam menganalisis situasi sosial, terutama masalah yang menyangkut hubungan antar pribadi anak. Pemecahan masalah dilakukan secara demokratis.

Dalam hal ini, bermain peran diarahkan pada pemecahan masalah yang menyangkut hubungan antarmanusia, terutama kehidupan anak. Manusia merupakan makhluk sosial dan individual, yang dalam hidupnya senantiasa berhadapan dengan manusia lain atau situasi di sekelilingnya. Sebagai individu, manusia memiliki pola yang unik dalam berhubungan dengan manusia lain. Ia memiliki rasa senang, tidak senang, percaya, curiga, dan ragu terhadap orang lain. Namun, perasaan tersebut diarahkan juga pada dirinya. Perasaan dan sikap terhadap orang lain dan dirinya itu mempengaruhi pola respon terhadap individu lain atau situasi di luar dirinya.

Bermain peran berusaha membantu individu memahami perannya sendiri dan peran yang dimainkan orang lain sambil mengerti perasaan, sikap dan nilai yang mendasarinya. Bermain peran dalam pembelajaran merupakan usaha untuk memecahkan masalah melalui peragaan, serta langkah-langkah identifikasi masalah, analisis, pemeranan, dan diskusi. Untuk kepentingan tersebut, sejumlah anak bertindak sebagai pemeran dan yang lainnya sebagai pengamat. Seorang pemeran harus mampu menghayati peran yang dimainkannya. Melalui peran, anak berinteraksi dengan orang lain yang juga membawakan peran tertentu sesuai dengan tema yang dipilih.

Selama pembelajaran berlangsung, setiap pemeran dapat melatih sikap empati, simpati, rasa benci, marah, senang, dan peran lainnya. Pemeran tenggelam dalam peran yang dimainkannya, sedangkan pengamat melibatkan dirinya secara emosional dan berusaha mengidentifikasikan perasaan dengan perasaan yang tengah bergejolak dan menguasai pemeranan.

Hakikat bermain peran terletak pada keterlibatan emosional pemeran dan pengamat dalam situasi masalah yang secara nyata dihadapi. Melalui bermain peran dalam pembelajaran, diharapkan para anak dapat: (a) mengeksplorasi perasaannya; (b) memperoleh wawasan tentang sikap, nilai, dan persepsinya; (c) mengembangkan keterampilan dan sikap dalam memecahkan masalah yang dihadapi; dan (d) mengeksplorasi inti permasalahan yang diperankan melalui berbagai cara.

Berdasarkan latar belakang tersebut, maka perlu dilakukan penelitian mengenai pengaruh penerapan konseling dengan teknik bermain peran terintegrasi dalam mengembangkan kemampuan sosialisasi pada siswa yang terisolir. Secara umum, penelitian yang dilakukan bertujuan untuk meningkatkan kemampuan interaksi sosial pada siswa yang terisolir melalui kegiatan permainan "Elang dan Anak Ayam".

\section{METODE PENELITIAN}

Penelitian ini dilaksanakan dengan menggunakan metode eksperimen, yaitu metode penelitian yang berusaha melihat pengaruh variabel independen atau variabel bebas pada satu atau lebih variabel dependen atau terikat (Kerlinger, 1986:345). Variabel pertama merupakan perlakuan, sementara variabel kedua adalah hasil (outcomes) yang diperoleh setelah penerapan perlakuan. Rancangan yang digunakan adalah single subject research design. Desain dengan satu subjek penelitian merupakan sebuah penelitian eksperimen, di mana peneliti membantu atau memberikan perlakuan kepada partisipan di bawah kontrol dirinya sendiri (Gast, 2010:13-14). Selanjutnya, data masing-masing partisipan dicatatkan mengenai kondisi intervensi yang diberikan dan kemajuan perkembangannya. Data tersebut kemudian disajikan dalam bentuk grafik kemajuan perkembangan. Desain yang digunakan adalah A - B, yang dapat dilihat pada gambar 1.

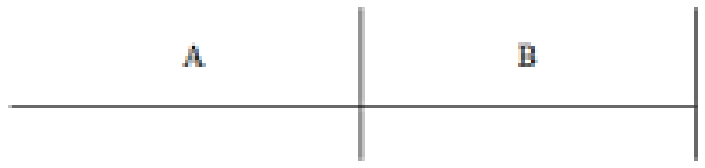

Keterangan:

A: fase baseline, merupakan kondisi dimana intervensi belum diberikan

B: fase intervensi, kondisi dimana perlakuan sedang diberikan

Gambar 1. Desain penelitian

Variabel bebas dalam penelitian ini adalah kegiatan bermain "Elang dan Anak Ayam", sedangkan variabel terikatnya yaitu kemampuan berinteraksi sosial. Subjek penelitian ini adalah siswa kelas III/b SD yang berjumlah satu orang, di SDN Utan Kayu Selatan 13 Pagi, Jakarta Timur. Subjek merupakan siswa yang dijauhi teman-temannya, berjenis kelamin laki-laki. Pengumpulan data dilakukan dengan cara observasi langsung dan wawancara pada bulan Oktober sampai dengan Desember 2013. Setelah data dikumpulkan, dianalisis dengan menggunakan inspeksi visual, di mana 
analisis dilakukan dengan melakukan secara langsung terhadap data yang telah ditampilkan dalam grafik, yaitu analisis dalam kondisi dan analisis antarkondisi.

Terdapat delapan tahapan yang dilakukan peneliti dalam rancangan eksperimen. Masing-masing tahapan adalah: (1) penentuan masalah penelitian, di sini peneliti ingin mengetahui secara empiris apakah terdapat pengaruh penerapan konseling dengan teknik bermain peran terintegrasi dalam mengembangkan kemampuan sosialisasi pada siswa yang terisolir; (2) merumuskan hipotesis penelitian untuk menguji hubungan sebab akibat antara variabel-variabel yang diukur; (3) peneliti menentukan subjek eksperimen (E); (4) menentukan jenis perlakuan, dalam hal ini rancangan kegiatan bermain peran; (5) memilih desain eksperimen yang sesuai, peneliti menggunakan desain single subject research; (6) menerapkan perlakuan, diawali dengan melakukan pretest pada variabel terikat dari kelompok tersebut; (7) mengadministrasikan perlakuan (variabel independen), yaitu kegiatan bermain peran yang terintegrasi dengan kegiatan pembelajaran, kemudian melakukan postest setelah perlakuan diberikan terhadap sampel penelitian; (8) peneliti menetapkan efek eksperimen dan melaporkan hasilnya (Creswell, 2008:325-328).

\section{HASIL DAN PEMBAHASAN}

\section{Hasil Penelitian}

Pengukuran tingkat interaksi sosial dengan pedoman pengamatan berupa Skala Interaksi Sosial dilakukan kepada subjek penelitian yang berjumlah satu orang siswa kelas III/b, SDN Utan Kayu Selatan 13 Pagi. Berdasarkan hasil pengukuran pada subjek sebelum dan sesudah diintervensi dengan kegiatan bermain peran "Elang dan Anak Ayam" yang terintegrasi dengan pelajaran olahraga, maka visual data yang menggambarkan skor dua kondisi di atas dapat dilihat pada tabel 1 .

Tabel 1. Data Deskriptif Tingkat Interaksi Sosial Siswa

\begin{tabular}{|l|c|c|c|c|c|c|c|}
\hline $\begin{array}{c}\text { Klmpk. } \\
\text { data }\end{array}$ & $\begin{array}{c}\text { Skor } \\
\text { Min. }\end{array}$ & $\begin{array}{c}\text { Skor } \\
\text { Maks. }\end{array}$ & $\begin{array}{c}\text { Mean } \\
\text { Level }\end{array}$ & Rentang & $\begin{array}{c}\text { Batas } \\
\text { Bawah }\end{array}$ & $\begin{array}{c}\text { Batas } \\
\text { Atas }\end{array}$ & Median \\
\hline Baseline & 50.00 & 62.50 & 57.00 & 8.55 & 52.73 & 61.28 & 57.50 \\
\hline $\begin{array}{l}\text { Interven- } \\
\text { tion }\end{array}$ & 62.50 & 82.50 & 71.50 & 10.74 & 66.13 & 76.87 & 72.50 \\
\hline
\end{tabular}

Data pada tabel 1 menunjukkan mean level skor tingkat interaksi sosial siswa pada kondisi baseline adalah sebesar 57.00, sedangkan mean level setelah intervensi meningkat menjadi 71.50. Perolehan skor minimum dan maksimum pada kondisi awal (base line) masing-masing 50.00 dan 62.50. Sementara itu, skor minimum dan maksimum pada kondisi intervensi adalah 62.50 dan 82.50. Pada skor minimum, sebelum dan sesudah perlakuan, mengalami peningkatan sebesar 12.50 poin, sedangkan skor maksimumnya mengalami peningkatan sebesar 20 poin. Berikutnya, rentang stabilitas pada dua kondisi adalah 8.55 untuk kondisi awal, dan 10.73 pada kondisi intervensi. Berdasarkan perhitungan rentang stabilitas, dapat ditentukan batas bawah dan batas atas kedua kondisi. Batas bawah pada baseline data diketahui sebesar 52.73 dan batas atas adalah 61.28. sementara itu, batas pada kondisi intervensi, batas bawahnya adalah 66.13, sedangkan batas atas sebesar 76.87. Gambaran mengenai perolehan skor interaksi sosial siswa sebelum dan sesudah perlakuan dapat dilihat pada gambar 2 .

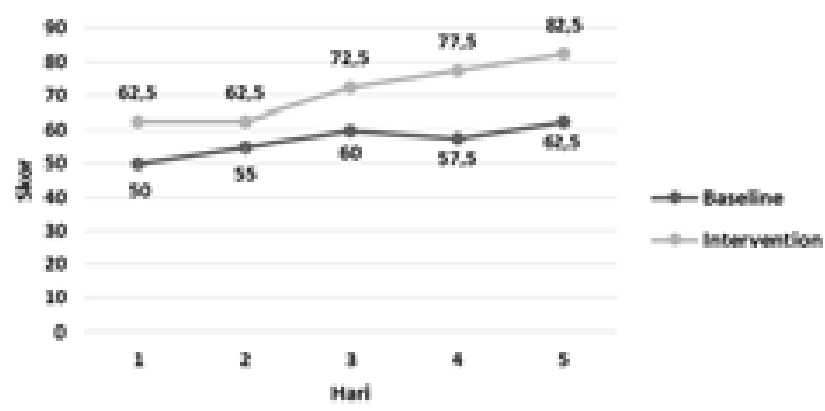

Gambar 2. Kondisi fase baseline dan intervensi

Berdasarkan data yang ditunjukkan pada gambar 2, hasil penelitian menunjukkan bahwa terjadi peningkatan kemampuan interaksi sosial pengaruh penerapan konseling dari kondisi Baseline ke Intervention.

\section{Pembahasan}

Data yang disajikan pada gambar 2 menjelaskan bahwa tingkat interaksi sosial subjek penelitian meningkat antara sebelum dan sesudah diberikan intervensi. Intervensi berupa layanan konseling anak melalui teknik bermain peran terintegrasi, dalam hal ini melalui permainan "Elang dan Anak Ayam" yang diintegrasikan dalam mata pelajaran olah raga. Penerapan teknik bermain peran dirasa cukup signifikan dalam meningkatkan interaksi sosial. Permainan ini telah membantu siswa berinteraksi dengan siswa lain untuk saling bekerja sama serta saling melindungi antar-teman.

Melalui bermain "Elang dan Anak Ayam", anak dapat mengeksplorasi perasaannya. Berdasarkan hasil pengamatan selama berlangsungnya permainan, "Induk Ayam" dapat memainkan perannya secara penuh. Semua perilaku anak yang dimunculkan bersifat spontan dan anak bermain tanpa beban. Tanpa harus menggurui dan menjejali anak dengan berbagai nasehat, sebenarnya anak dapat menampilkan perilaku positif, dan potensi ini dapat digali melalui permainan. 
Dengan melakukan permainan "Elang dan Anak Ayam", anak juga memperoleh wawasan tentang sikap, nilai, dan persepsinya. Setelah selesai melakukan permainan, peneliti bersama anak mendiskusikan aktivitas yang telah mereka lakukan. Ketika ditanyakan mengenai perasaannya, semua anak merasa senang, bahkan menginginkan permainan diteruskan. Bagian yang paling pokok, yaitu mendiskusikan peran masing-masing. Anak dapat mengungkapkan gambaran peran yang dimaksud dan menyimpulkan bahwa elang yang gemar memangsa anak ayam dinilai tidak baik, sementara induk ayam mempunyai tugas yang berat karena harus melindungi anak-anaknya dari kejaran elang.

Selain itu, anak juga dapat mengembangkan keterampilan dan sikap dalam memecahkan masalah yang dihadapi serta mengeksplorasi inti permasalahan yang diperankan. Hal ini terlihat dari anak yang mampu mengevaluasi diri sendiri dan temannya apakah sudah berperan sesuai yang diharapkan. Hasilnya, terbentuk persepsi baru mengenai anak yang ditunjuk sebagai induk ayam cukup berhasil.

Berdasarkan uraian tersebut, dapat dikatakan bahwa melalui permainan "Elang dan Anak Ayam" dapat meningkatkan kemampuan interaksi sosial pada siswa yang terisolir. Peningkatan kemampuan siswa dalam melakukan interaksi sosial meliputi indikator, interaksi positif dengan teman sebaya, berpartisipasi dalam aktivitas kelompok, dan responsif terhadap orang lain.

Namun demikian, berdasarkan analisis peneliti, umumnya anak tidak mengenal dan tidak tahu cara memainkan "Elang dan Anak Ayam". Hal ini menjadi keprihatinan bagi peneliti karena permainan tradisional yang sebenarnya sangat bermakna bagi anak, saat ini hampir punah dan tidak lagi populer dibandingkan era 80-an dan sebelumnya. Anak-anak rupanya lebih familiar dengan permainan-permainan elektronik (PS misalnya), atau alat-alat permainan edukatif yang populer, seperti lego, puzzle, dan sejenisnya.

\section{PENUTUP}

\section{Kesimpulan}

Melalui kegiatan yang telah dilakukan, beberapa hal yang dapat disimpulkan. Pertama, bermain memiliki pengaruh dalam tumbuh kembang seorang anak. Dalam konteks ini, bermain tidak hanya mengandung esensi membuat anak menjadi gembira, tetapi merupakan sarana atau cara anak untuk belajar tentang tubuhnya, lingkungan, ide-ide, kejadian, orang atau objek-objek di sekelilingnya. Kedua, bermain dapat digunakan sebagai media intervensi terhadap anak-anak dengan masalah tertentu. Ketiga, bagi anak-anak yang terisolir dalam kelompoknya karena agresif, permainan "Elang dan Anak Ayam", khususnya dapat dijadikan sebagai media intervensi. Prosedur permainan dapat dikembangkan oleh guru atau orang dewasa lainnya, yaitu peran induk ayam yang semula dipilih melalui suten, dapat langsung diperankan oleh anak yang dimaksud dan ditunjuk oleh guru. Melalui permainan ini, anak diajak bermain peran untuk mempelajari keterampilan-keterampilan baru dalam bersosialisasi dengan teman sebayanya. Kemampuan anak untuk melindungi, menjaga, dan menolong temannya dibangun lewat peran yang dimainkan. Keefektifan permainan ini dapat dirasakan setelah dilakukan beberapa kali dalam jangka waktu tertentu agar anak terus terlatih menampilkan perilaku positif dalam perannya sebagai "Induk Ayam". Dengan demikian dapat dikatakan bahwa terdapat pengaruh antara penerapan konseling dengan teknik bermain peran terintegrasi dalam mengembangkan kemampuan sosialisasi pada siswa yang terisolir. Peningkatan kemampuan siswa dalam melakukan interaksi sosial meliputi indikator, interaksi positif dengan teman sebaya, berpartisipasi dalam aktivitas kelompok, dan responsif terhadap orang lain

\section{Saran}

Berdasarkan hasil penelitian dan kesimpulan, terdapat beberapa saran. Pertama, peneliti menyarankan agar guru atau pendidik anak usia dini dapat mengembangkan berbagai metode pembelajaran yang dapat meningkatkan kemampuan interaksi sosial pada siswa yang terisolir. Salah satunya, yaitu melalui bermain peran. Kedua, permainan yang digunakan sebagai metode pembelajaran sebaiknya permainan tradisional, karena selain untuk kepentingan pembelajaran, juga merupakan salah satu upaya melestarikan budaya bangsa, sehingga anak tidak kehilangan identitasnya. Pengembangan permainan tidak hanya dimaksudkan untuk mengembangkan kemampuan kognitif anak, tetapi tetap memperhatikan pengembangan aspek lainnya. Ketiga, orang tua juga diharapkan berperan aktif dalam membelajarkan anak mengenai nilai-nilai tertentu atau mengenai keterampilan tertentu juga dapat dilakukan melalui bermain.

\section{DAFTAR PUSTAKA}

Clark, B. (1986). Growing up gifted. Columbia, USA: CE Merril Publishing Co.

Creswell, J. W. (2008). Research design: Qualitative, quantitative, and mixed methods approaches. London: 
SAGE Publications, Incorporated.

Gast, D. L. (2010). Single subject research methodology in behavioral science. New York: Routledge

Kerlinger, F.N. (1986). Foundations of behavioral research. 3rd edition. Orlando, FL: Harcourt Brace \& Company.

Naisaban, L. (2012). Bergembira bersama 100 permainan rakyat. Jakarta: Grasindo, 2002.

Patmonodewo, S. (2002). Pendidikan anak prasekolah. Jakarta: Rineka Cipta.

Peraturan Pemerintah No.28 Tahun 1990 tentang
Pendidikan dasar.

Permendiknas No. 22 Tahun 2006 tentang Standar Isi.

Semiawan, C. (2002). Belajar dan pembelajaran dalam taraf pendidikan usia dini: Pendidikan prasekolah dan sekolah dasar. Jakarta: Prenhallindo.

Undang-undang No. 20 Tahun 2003 tentang Sistem pendidikan nasional.

Vasta, R., Haith, M.M.,\& Miller, S.A. (1999). Child psychology: The modern science. 3th ed., New York: John Wiley \& Sons, Inc. 